\title{
PRELIMINARY OBSERVATIONS ON THE ROLE OF THE COELOMIC CELLS IN FOOD STORAGE AND TRANSPORT IN CERTAIN POLYCHAETES
}

\author{
By R. Phillits Dales \\ Department of Zoology, Bedford College, University of London
}

(Text-figs. I, 2)

\section{INTRODUCTION}

To what extent food may be stored, and where such stores may be found in the polychaete body is virtually unknown. There are four main sites where the more detailed economy may take place: in the wall of the gut, in the epidermal layers, in the peritoneum, and in the cells or tissue found within the coelom. The mechanism for the removal of waste products is no better understood than the stages in the utilization and transport of absorbed nutrients. What little information exists is for the most part contradictory and unsupported by quantitative measurement.

While it is hoped to review the function of the chloragocytes in connexion with excretion in a later paper, some discussion of the function of these cells is necessary here in view of their possible relation with food storage and with the identity of the different cells found in the coelomic fluid.

It will be appreciated that most of the work on chloragocytes has been done on oligochaetes, and the identification of these cells in polychaetes has been made by analogy. While there is an extensive literature on coelomic cells (see the bibliographies of Romieu (1923) and Liebman (1946)), the only detailed work on polychaetes is that of Schaeppi (1894) on Ophelia, apart from brief descriptions of chloragocytes and general information in the papers of Schneider (1897, 1899) and Picton (I898). There seems to be little agreement about the chemical nature of the chloragosomes or granules occurring within the chloragocytes, and almost any tissue of a yellow or green colour associated with blood vessel or gut has been described as 'chloragogenous' by different writers.

Briefly, there are two main views regarding the function of the chloragocytes and the identity of the chloragosomes. According to one view, the chloragosomes are excretory substances which are liberated by the chloragocytes into the coelomic fluid where they may be taken up by amoebocytes and transported to the nephridia, the gut epithelium, or stored as 'brown bodies'. Supporters of this theory (Cuénot, 1898; Rosa, 1896, 1898; Schneider, 1896, I899; Willem \& Minne, I900; Kollman, 1908; Romieu, I923; Abdel- 
Fattah, 1955) have described the chloragosomes as consisting of guanin, urates, urea or chitin. Opponents of this view maintain that the chloragosomes represent stored food materials - fat, glycogen, or albumin-and have no relation to excretion. The main exponent of this idea in recent years is Liebman (1946) working on earthworms.

Liebman recognizes two types of cell which he calls lymphoidocytes (here called amoebocytes) which are small, amoeboid cells, and trephocytes which produce, distribute and release nutritive substances into the blood and tissues. Liebman departs from the interpretation of others in identifying the trephocytes with chloragocytes which have become free; in them he traces three stages: (I) cells in which neutral fat is present, (2) those in which phospholipid appears, and (3) cells in which the lipid granules are released into the coelomic fluid or tissues. Liebman infers that the blood in such animals participates little in the transport of nutrients through the body, and that on the contrary it is the 'chloragogue' or trephocyte system which has been elaborated to serve this function. Liebman, however, uses the term 'chloragogue' in a very wide sense to include all the cells covering the gut. He has found in Eisenia foetida that wound healing is aided by the aggregation of coelomic trephocytes in the region of the wound, the cells liberating their lipid granules which are then taken up and utilized by the proliferating tissue. Liebman equates the trephocytes with the 'eleocytes' of polychaetes. To what extent this may be justified is discussed later. Issel (1905), working on the enchytraeid Henlea, found that the chloragogen covering of the gut was entirely lost at the time of the development of the oocytes, and concluded that this was evidence for the trophic nature of the chloragocytes. Freudweiler (I905) came to the same conclusion in her work on another enchytraeid, Stercutus, visualizing the liberation of the chloragosomes (which she also identifies as lipid) into the coelomic fluid with their subsequent uptake by the oocytes.

Those supporting the excretory hypothesis agree that the chloragocytes are modified peritoneal cells in contact with some branch of the intestinal blood system, and that they are not modified amoebocytes (Rosa, I898; Rice, I902; Sterling, I908). The chloragosomes were thought to be guanine by Willem \& Minne (1900), who strongly oppose the existence of any fat in the chloragocytes, though both Schneider (1896) and Freudweiler (1905) describe fat in these cells. Cuénot (1898) argued that glycogen, which occurs in large amounts in the peritoneum, is the main storage substance in earthworms, and that the view that the chloragosomes are lipid in nature does not justify the conclusion that they represent important food stores. More recently, AbdelFattah (1955) identifies urea in the chloragocytes, and opposes the views of Willem \& Minne (I900) in identifying the chloragosomes as guanine. AbdelFattah (1955) finds no evidence for the chloragocytes becoming free.

Clearly much of this confusion has resulted from differences in interpretation in the origin and history of the coelomic amoebocytes and trephocytes. 
Willem \& Minne (1900) regard the chloragocytes as storing the waste products which are later taken up by amoebocytes, and they oppose the view that the chloragocytes themselves become free as Liebman maintains. Romieu (1923), Kollman (1908) and Rosa (I898) derive the trephocytes from amoebocytes, and Romieu identifies in various polychaetes, both fat and excretory substances in these cells.

In polychaetes the increase in abundance of the trephocytes during the early development of the gametes has been noted by a number of observers (Claparède, I868, I873; Cuénot, I89I ; Romieu, I92I ; Fauré-Fremiet, I929; Herpin, I92I; Dales, I950), and this implies a nutritive function. None of these writers has identified these trephocytes with chloragocytes or suggested a connexion with excretion.

Some knowledge of the quantities of fat and glycogen in different parts of the body, especially in the trephocytes at different seasons, would aid the elucidation of these problems in polychaetes, and this is the main purpose of the present paper. It is hoped to extend the work in much greater detail.

The species studied were selected for various reasons. Both Amphitrite johnstoni Malmgren and Arenicola marina (L.) are large and have few septa, so that the collection of the coelomic fluid and contained corpuscles can be reasonably complete. While both species spawn in autumn, Amphitrite has a large number of trephocytes at all times, but Arenicola has very few. Nereis diversicolor O. F. Müller does not lend itself well to this type of study, not only because of its smaller size, but because of the virtual impossibility of collecting the whole coelomic contents owing to the septa. Some determinations of the fats in the body wall and gametes have been made, however, in the light of earlier work (Dales, 1950; Dales \& Kennedy, 1954). A few observations have been made on Terebella lapidaria (Kahler) for comparison with Amphitrite, as the trephocytes differ in containing haemoglobin. The Amphitrite were all collected at Noss Mayo, near Plymouth, Arenicola from Plymouth and from Chalkwell, Essex, where the Nereis were also collected.

Much of this work has been done in the Plymouth Laboratory, and I wish to thank the Director, and Dr L. H. N. Cooper and other members of the staff for help in various ways. In particular I have to thank Mr R. Tozer for collecting Amphitrite at times when I could not be at Plymouth, and Dr G. Y. Kennedy for assistance with the analysis of the coelomic cells in Amphitrite and Terebella. I also wish to thank Mr M. A. Gross for taking the photographs illustrated in Fig. 2.

\section{METHODS}

Bloor's methods (1928, I929) for the analysis of the fat constituents of blood plasma were adapted for the estimation in the different tissues of total fat (estimated as total fatty acids plus sterols) and phospholipid. Cholesterol was 
estimated by Sperry's method (1938). After some practice total fats could be estimated to an accuracy of $\pm 2 \%$ with samples of 50 - $100 \mathrm{mg}$ of tissue (2-5 mg fat); cholesterol could be estimated rather more accurately; values for phospholipid were found to be less reliable, and have been mostly disregarded. Full details of the procedure adopted in the analysis of the fat are given in the Appendix; the main principles are outlined below.

Extraction was effected with boiling $95 \%$ ethanol:ether 3:I mixture; the extract was made up to a known volume which was then sampled for estimation of total fat, phospholipid, and sterol fractions. For the estimation of total fats, a portion of the extract was saponified, the solvent evaporated off and the pasty residue treated with hot $\mathrm{H}_{2} \mathrm{SO}_{4}$ to liberate the fatty acids which were then re-extracted with boiling light petroleum. A known quantity of the solution was evaporated to dryness and the fatty acids estimated by oxidation with a chromic acid mixture against a control, followed by back titration with sodium thiosulphate. Phospholipids were estimated by evaporating a portion of the original extract to dryness, re-extracting with light petroleum and then precipitating the phospholipids with acetone and magnesium chloride. The precipitate was washed repeatedly with acetone, and redissolved in ether; a measured quantity evaporated to dryness, and the residue estimated by the chromic acid procedure as before. Total sterols were estimated by treating a portion of the original extract with caustic alkali, and after neutralization, precipitating the sterols as their digitonides. After purification the amount present was estimated by the Liebermann-Burchard reaction, the density of the colour produced being measured in a spectrophotometer against a cholesterol standard at $670 \mathrm{~m} \mu$.

For the estimation of glycogen the sample of tissue (about $50 \mathrm{mg}$ ) was placed in ethanol at $0^{\circ} \mathrm{C}$, or directly in $3 \mathrm{ml}$. of $30 \% \mathrm{KOH}$ and refluxed for $2 \mathrm{~h}$. An excess of $95 \%$ alcohol was then added to the solution, the tube dipped into a boiling water-bath for I min, and then allowed to stand overnight. The precipitate was washed twice in absolute alcohol, and the precipitate repeatedly centrifuged. The walls of the tube were finally washed down with Io $\mathrm{ml}$. of approximately $0.6 \mathrm{~N}-\mathrm{HCl}$ and then heated under reflux for $3 \mathrm{~h}$. After cooling, the solution was neutralized with $\mathrm{I} \cdot 0 \mathrm{~N}-\mathrm{NaOH}$ against thymol blue, made up to a known volume, and the glucose so formed estimated by the method of Hagedorn \& Jensen (1923). For this a Rehberg microburette was used; Krogh pipettes were used for the more critical measurements.

The histochemical work was done in the light of the recent work of Baker (1946) and Cain (1947) for fats, and Smyth \& Hopkins (1948) for glycogen. While living coelomic cells in all forms were examined whenever possible, permanent preparations for fat distribution were made of tissue fixed in Baker's formal-calcium, and for glycogen in Best's picro-formal fixative at $0^{\circ} \mathrm{C}$. For the study of glycogen, tissues were kept in absolute alcohol at $0^{\circ} \mathrm{C}$ until embedded in ester wax as recommended by Smyth \& Hopkins (1948). 
Best's carmine method was used for subsequent staining against diastase controls as recommended by Pearse (1953). In the study of fats, frozen sections were cut of whole tissues fixed in formal-calcium. Smears were made of the living coelomic cells (without addition of albumin) and fixed in the same way. Sudan black B, acetylated according to the technique of Casselman (1954) was used to localize the fats, the stain being dissolved either in $70 \%$ alcohol, or in propylene glycol (Chiffelle \& Putt, I95I), against hot pyridine controls. The latter method seemed to give more delicate results. Baker's acid haematin method (I946) for phospholipids, and Cain's nile blue method (I947), staining and differentiating at $37^{\circ} \mathrm{C}$, were also used, Gurr's glycerine jelly being employed as mountant in most cases.

\section{RESULTS}

Fats

\section{Amphitrite johnstoni}

Determinations of total fats in various tissues at different seasons are given in Table I, and the arithmetic means are compared graphically in Fig. I. The values for all tissues are highest in August, and the difference between the August values and those for November are significantly different for all tissues. The differences in the other values for body wall and gut are not statistically significant, and the higher April value compared with the February value for the coelomic cells only possibly significant. It can be concluded from these figures that the gut wall has the highest concentration of fat in the body at all times, and that the value is highest in August and lowest in November shortly after spawning. This suggests that the gut is to a certain extent a fat store. The body has the lowest value for fat concentration, but this may be due to the large proportion of muscular tissue which has a lower fat content than the epidermis. It is possible that the fat content of the epidermal layers is very similar to that of the gut, and it is this layer which may cause the seasonal change in values for body wall. The variation in value for coelomic contents reflects the quantity of gametes present; the value is highest in August owing to the large quantity of mature gametes, and low in November after spawning. The fat content of the nearly ripe oocytes and the trephocytes is similar. In August-September the cells and the oocytes may be separated almost completely by centrifugation. Spermatids and sperm contain much less fat, but the total fat in the coelom of a ripe male is much the same as that of a ripe female. The results of determinations of twelve randomly selected worms is shown in Table 2. The mean wet weight of the females was $9.35 \mathrm{~g}$, of which $2.86 \mathrm{~g}$ was represented by the coelomic fluid and $0.95 \mathrm{~g}$ by the coelomic cells. In a ripe female, therefore, about $36 \mathrm{~g}$ of fat is represented by the oocytes and trephocytes, which is about half the total quantity in the remainder of the body at this time. During the early stages of maturation of the oocytes (JanuaryFebruary) when they are similar in size to the trephocytes, sudan black B 
TABLE 1. CONCENTRATION OF FAT IN AMPHITRITE FOHNSTONI AT DIFFERENT SEASONS (MG/G WET WEIGHT)

\begin{tabular}{|c|c|c|c|c|}
\hline & $\begin{array}{l}\text { August } \\
\text { (1955) }\end{array}$ & $\begin{array}{c}\text { November } \\
\text { (1955) }\end{array}$ & $\begin{array}{l}\text { January- } \\
\text { February } \\
\text { (1956) }\end{array}$ & $\begin{array}{c}\text { April } \\
\text { (1956) }\end{array}$ \\
\hline \multirow[t]{5}{*}{ Body wall } & $\begin{array}{r}7 \cdot 37 \\
76.60\end{array}$ & $10 \cdot 60$ & $\begin{array}{r}3.83 \\
7.00\end{array}$ & $\begin{array}{l}5.00 \\
8.00\end{array}$ \\
\hline & II. 45 & 8.05 & 7.95 & 10.00 \\
\hline & 15.00 & 3.65 & $6 \cdot 25$ & I5.90 \\
\hline & 16.00 & $7 \cdot 20$ & $7 \cdot 80$ & $6 \cdot 30$ \\
\hline & 15.20 & - & $8 \cdot 10$ & 5.90 \\
\hline Mean & 13.60 & $7 \cdot 96$ & $6 \cdot 80$ & $8 \cdot 70$ \\
\hline \multirow[t]{5}{*}{ Gut } & $38 \cdot 40$ & $31 \cdot 80$ & $42 \cdot 50$ & 30.50 \\
\hline & $42 \cdot 50$ & $23 \cdot 20$ & $26 \cdot 80$ & 39.40 \\
\hline & $55 \cdot 20$ & I4.90 & $35 \cdot 10$ & 44.50 \\
\hline & $47: 40$ & $4 \mathrm{I} \cdot 70$ & $49 \cdot 40$ & $5 \mathrm{I} \cdot 50$ \\
\hline & 54.70 & 19.90 & $30 \cdot 10$ & $47 \cdot 20$ \\
\hline Mean & $46 \cdot 40$ & $\begin{array}{l}25 \cdot 70 \\
26 \cdot 20\end{array}$ & $\begin{array}{l}25 \cdot 30 \\
34.90\end{array}$ & $\overline{42} \cdot 60$ \\
\hline \multirow[t]{6}{*}{ Coelomic cells } & $45 \cdot 20$ & 15.70 & $12 \cdot 10$ & $2 \mathrm{I} \cdot 3 \mathrm{O}$ \\
\hline & 35.90 & 12.00 & 12.40 & $2 \mathrm{I} \cdot \mathrm{IO}$ \\
\hline & 29.50 & 6.80 & 8.50 & I 4.40 \\
\hline & $52 \cdot 80$ & $I \cdot 20$ & $9 \cdot 30$ & $7 \cdot 60$ \\
\hline & $51 \cdot 20$ & - & 10.20 & 26.90 \\
\hline & $36 \cdot 50$ & - & II 60 & \\
\hline Mean & $4 \mathrm{I} \cdot 85$ & 8.90 & 10.68 & 18.30 \\
\hline
\end{tabular}

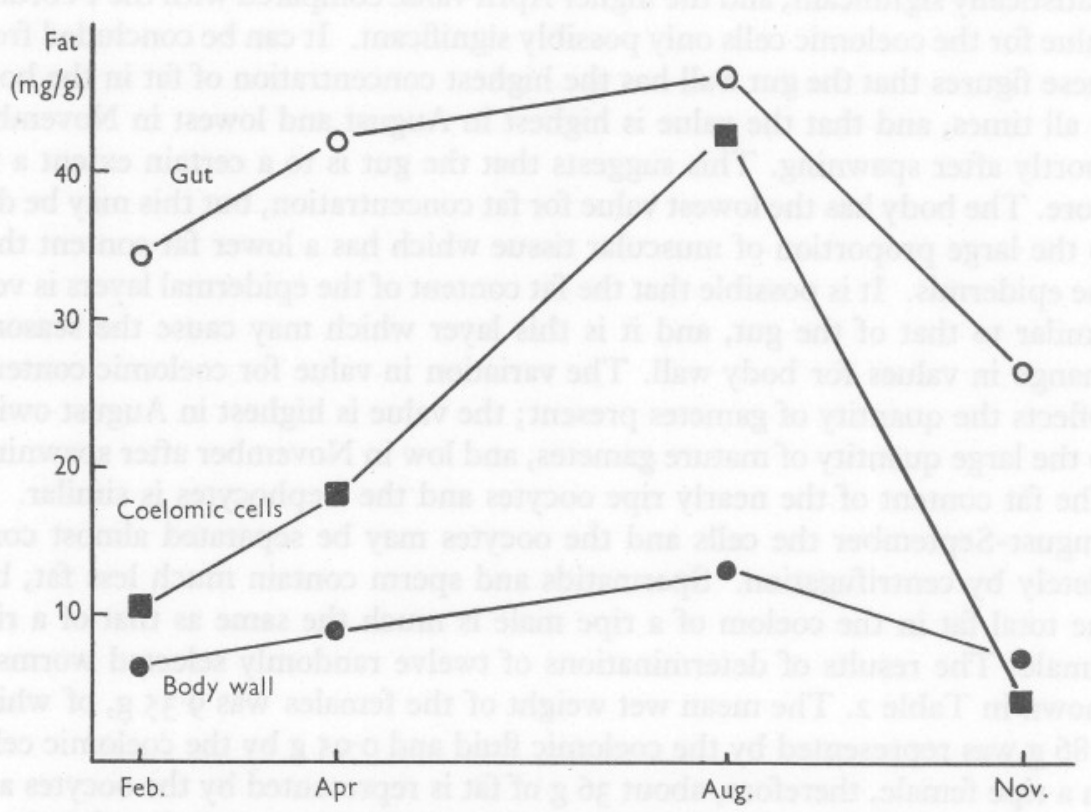

Fig. I. Mean concentration of fat in Amphitrite johnstoni at different seasons ( $\mathrm{mg} / \mathrm{g}$ fresh weight) 
staining showed no more fat in the oocytes than in the trephocytes. At this time, six worms of mean weight $9.0 \mathrm{~g}$ gave a mean total value of $6.1 \mathrm{mg}$ of fat represented by the coelomic cells. There is about six times this quantity in the gut. The proportion by weight of the different parts of the body of three randomly selected worms is shown in Table 3 .

\begin{tabular}{|c|c|c|c|}
\hline & Trephocytes & Oocytes & $\begin{array}{l}\text { Sperma- } \\
\text { tids/sperm }\end{array}$ \\
\hline Weight analysed & $\begin{array}{l}\text { (I) } 2.985 \mathrm{~g} \text { (female) } \\
\text { (2) } 3.667 \mathrm{~g} \text { (male) }\end{array}$ & $\begin{array}{l}\text { (I) } 4.927 \mathrm{~g} \\
\text { (2) } 7.332 \mathrm{~g}\end{array}$ & (2) $\overline{334 \mathrm{~g}}$ \\
\hline Total fat & $\begin{array}{l}\text { (I) } 45 \cdot 2 \\
\text { (2) } 35.9\end{array}$ & $\begin{array}{l}\text { (I) } 3 I \cdot 8 \\
\text { (2) } 42 \cdot 2\end{array}$ & $10 \cdot 2$ \\
\hline Phospholipid & $\begin{array}{l}\text { (I) } 12 \cdot 0 \\
\text { (2) } 15 \cdot 3\end{array}$ & $\begin{array}{l}\text { (I) } 15.0 \\
\text { (2) } 19 \cdot 4\end{array}$ & -6.9 \\
\hline Total sterols & $\begin{array}{ll}\text { (I) } & 3 \cdot 3 \\
\text { (2) } & 3 \cdot 4\end{array}$ & $\begin{array}{ll}\text { (I) } & 3 \cdot 5 \\
\text { (2) } & 4 \cdot I\end{array}$ & $\stackrel{I \cdot 8}{-}$ \\
\hline
\end{tabular}

TABLE 3. AMPHITRITE FOHNSTONI, PROPORTION OF PARTS ANALYSED (G WET WEIGHT)

\begin{tabular}{|c|c|c|c|c|}
\hline & $\begin{array}{c}\text { Gross } \\
\text { weight }\end{array}$ & $\begin{array}{l}\text { Body } \\
\text { wall }\end{array}$ & Gut & $\begin{array}{c}\text { Coelomic } \\
\text { cells }\end{array}$ \\
\hline & 10.6 & 3.6 & 0.76 & $I \cdot 25$ \\
\hline & $9 \cdot 6$ & 3.0 & 0.56 & $1 \cdot 20$ \\
\hline & 9.I & $2 \cdot 4$ & 0.70 & $I \cdot 20$ \\
\hline Mean & 9.8 & 3.0 & 0.67 & $I \cdot 22$ \\
\hline
\end{tabular}

TABLE 4. AMPHITRITE GOHNSTONI, CONCENTRATION OF FAT IN DIFFERENT PARTS OF THE GUT (MG/G)

$\begin{array}{ccc}\text { Fore } & \text { Hind } & \\ \text { stomach } & \text { stomach } & \text { Intestine } \\ 6 \mathrm{I} \cdot 8 & 14 \cdot 0 & 82.5 \\ 87.3 & 18 \cdot 0 & 56.2\end{array}$

The concentration of fat in different parts of the gut was investigated, and the results of two determinations each containing guts from six worms, are shown in Table 4 . The values for the fore stomach and intestine are not significantly different, but the hind stomach, which is almost entirely muscular (Dales, I955), is much lower and this value is interesting in giving some idea of the fat content of muscle alone. The values for fore stomach and intestine are higher than for the trephocytes, though the greater weight of the trephocytes tends to equate the total amount of fat represented in the gut and the trephocytes in any worm.

\section{Glycogen}

The concentration of glycogen in different parts of the body is shown in Table 5. The low concentration in all parts of the gut contrasts strongly with the high fat values, though the concentrations in the body wall and the coelomic cells are roughly equivalent to the concentration of fats. Sections of body 
wall stained with Best's carmine showed most of the glycogen in the peritoneum, and as there is much less in the muscular layers which constitute a large proportion of the weight, the actual concentration in the peritoneum may be high. It is interesting that the values for the coelomic cells are not very different from the values for fat.

TABLE 5. AMPHITRITE FOHNSTONI, CONCENTRATION OF GLYCOGEN IN DIFFERENT PARTS OF THE BODY (MG/G WET WEIGHT)

\begin{tabular}{|c|c|c|c|c|}
\hline \multirow[b]{2}{*}{$\begin{array}{l}\text { Body } \\
\text { wall }\end{array}$} & \multirow[b]{2}{*}{$\begin{array}{l}\text { Coelomic } \\
\text { cells }\end{array}$} & \multicolumn{3}{|c|}{ Gut } \\
\hline & & $\begin{array}{c}\text { Fore } \\
\text { stomach }\end{array}$ & $\begin{array}{l}\text { Hind } \\
\text { stomach }\end{array}$ & Intestine \\
\hline $\begin{array}{l}\text { I } 3.7 \\
\text { II. } 6\end{array}$ & $\begin{array}{l}37 \cdot 4 \\
\mathrm{I} 8 \cdot \mathrm{I}\end{array}$ & $\begin{array}{l}3.5 \\
5.8\end{array}$ & $\begin{array}{l}2 \cdot 3 \\
I \cdot 4\end{array}$ & $\begin{array}{l}6 \cdot 2 \\
2 \cdot 0\end{array}$ \\
\hline $6 \cdot 9$ & $35^{\circ} 0$ & 3.6 & $I \cdot 7$ & $2 \cdot 3$ \\
\hline 10.5 & I3.3 & 3.6 & $I \cdot 4$ & 3.5 \\
\hline 19.2 & $29 \cdot 2$ & $7 \cdot 8$ & $3 \cdot 3$ & 2.8 \\
\hline $14 \cdot 2$ & 36.0 & $5 \cdot 8$ & $2 \cdot 0$ & 10.4 \\
\hline $5 \cdot 3$ & 15.5 & $5 \cdot 3$ & $2 \cdot 2$ & $I \cdot 5$ \\
\hline 10.5 & $44^{\circ} 9$ & $2 \cdot 8$ & $2 \cdot 3$ & 3.7 \\
\hline 14.7 & 18.9 & $6 \cdot 3$ & $\mathrm{I} \cdot 8$ & $2 \cdot 8$ \\
\hline $9 \cdot 7$ & $26 \cdot 4$ & $6 \cdot 7$ & $I \cdot 9$ & $5 \cdot 5$ \\
\hline I3. I & $16 \cdot 8$ & - & $I \cdot O$ & 3.5 \\
\hline $17 \cdot 4$ & $8 \cdot 4$ & - & - & $2 \cdot 7$ \\
\hline - & I6.8 & - & - & - \\
\hline - & $32 \cdot 0$ & - & - & - \\
\hline $12 \cdot 2$ & $25 \cdot 7$ & $5 \cdot 1$ & $\mathrm{I} \cdot 8$ & $3 \cdot 6$ \\
\hline
\end{tabular}

\section{Histochemical data}

Smears of the coelomic cells were made at all seasons and stained for fats and glycogen. Their appearance when stained with sudan black B is shown in Fig. 2. All the granules stain a dark black and the same granules stain dark blue with Cain's $0.02 \%$ nile blue and give a positive reaction with Baker's acid haematin, so that they are at least partly phospholipid in nature. No redstaining granules were ever found, either in the trephocytes or in other parts of the body with Cain's method, and positive results were always obtained with Baker's acid haematin test. From the quantitative data it is known that $30-50 \%$ of the total fatty acids in most tissues is phospholipid, so that these granules are presumably a mixture of neutral fat and phospholipid or possibly consist of neutral fat surrounded by a phospholipid shell. Purple-staining granules were in fact sometimes obtained with Cain's method, and the smaller granules of fat nearer the nucleus in the trephocytes often gave a rather greenish colour with $0.02 \%$ nile blue. These granules are about $2 \mu$ in diameter, the largest about Io $\mu$ in diameter. Glycogen is scattered throughout the cytoplasm and these granules are only $\mathrm{I}-2 \mu$ in diameter. Frozen sections of gut and body wall were made and stained with acetylated sudan black B. In the gut most of the fat is present in the epithelial cells rather than in the very thin peritoneum, and in the body wall most of the fat is in the epidermal layer. 


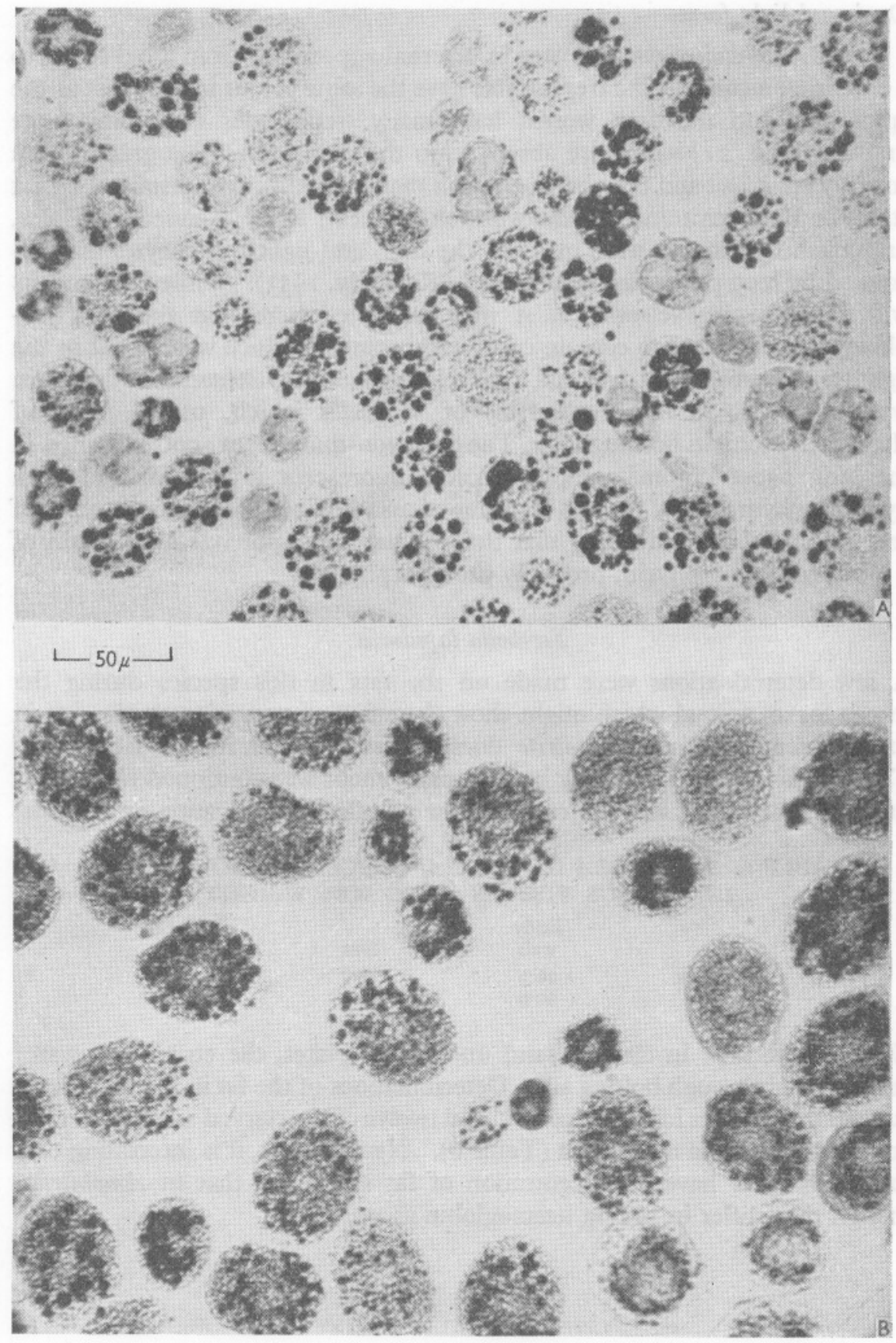

Fig. 2. Coelomic trephocytes of Amphitrite johnstoni, stained with acetylated sudan black B in propylene glycol. A: cells from the dark form showing the large unstained spherical granules. B: cells from the light form, lacking the spherical granules. 


\section{Dark and light forms}

Adult Amphitrite johnstoni vary in external appearance from a light pink to a dark brown colour. The trephocytes have the same colour in the mass as the epidermis, and the dark worms have many trephocytes containing large granules (Fig. 2A) which are absent from the pink form. The granules are roughly spherical and may be $12-15 \mu$ in diameter; they are unstained by fat stains or Best's carmine. In the work on the heart body (Kennedy \& Dales, unpublished) extracts were made of the dark and light trephocytes and examined by long paper chromatography (Kennedy, 1953). While these results will be published elsewhere, it may be noted here that the dark trephocytes were found to contain coproporphyrin III, which was absent in the light trephocytes. Both dark and light cells contained a haematin. A haematin was found also in the trephocytes of Terebella which, unlike those of Amphitrite, contain haemoglobin. The dark non-fluorescent spots obtained in the long paper chromatography became fluorescent after treatment with hydrazine hydrate and gave an $R_{F}$ value of $0.8 \mathrm{I}$ in Terebella and both types of cell in Amphitrite, indicating that the original dark spot was a haematin of a dicarboxylic porphyrin, probably protoporphyrin.

\section{Terebella lapidaria}

A few determinations were made on the fats in this species during the search for an animal which might show the effect of starvation on the fats in the different tissues. Amphitrite does not starve well in the laboratory; Terebella is rather more hardy but the experiment was continued for a short time only (Io days), and the results show no effect of starvation on the fats.

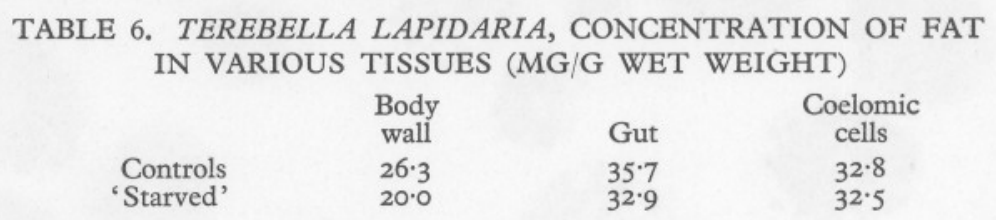

Worms were kept in cleaned sand under glass plates, the circulating water being passed through bolting silk. Determinations of the fat in the body wall, gut and trephocytes in twelve control and twelve of the starved animals showed no difference in the fat content (Table 6). Nevertheless, it is interesting that the trephocytes have a concentration of fat similar to that in Amphitrite, though they differ in having haemoglobin as well. 
Fats

\section{Arenicola marina}

The quantity of coleomic cells is very small at all seasons, though there is some increase during the maturation of the gametes, though even then the quantity of cells in the coelomic fluid is small compared with the quantity of gametes. The quantity of coelomic cells was measured at different times by filtering the whole of the coelomic fluid through oven-dried and weighed filter-paper and reweighing after drying at $100^{\circ} \mathrm{C}$. It was found that the value did not differ significantly over most of the year, and that the increase in weight of coelomic contents towards October was due entirely to the oocytes, which may be separated from the other cells by centrifugation. The detailed results are of little relevance in the present context, but it may be noted here that of sixteen worms of mean weight $3.15 \mathrm{~g}$ sampled in January, the mean dry

TABLE 7. ARENICOLA MARINA, CONCENTRATION OF FAT IN VARIOUS TISSUES (MG/G WET WEIGHT)

(November-December: six worms in each determination.)

\begin{tabular}{|c|c|c|c|c|}
\hline & & $\begin{array}{l}\text { Body } \\
\text { wall }\end{array}$ & Gut & $\begin{array}{l}\text { Coelomic } \\
\text { cells }\end{array}$ \\
\hline \multirow{3}{*}{ Normal } & & $\begin{array}{l}\text { I3.95 } \\
\text { II. } 20\end{array}$ & $\begin{array}{l}33 \cdot 20 \\
39 \cdot 70\end{array}$ & $\begin{array}{l}15.80 \\
26.00\end{array}$ \\
\hline & & II.95 & $13 \cdot 10$ & 39.00 \\
\hline & Mean & $12 \cdot 33$ & $28 \cdot 67$ & $26 \cdot 93$ \\
\hline $\begin{array}{l}\text { Starved } \\
\text { (6 weeks }\end{array}$ & & $2 I \cdot 75$ & 123.50 & $23 \cdot 60$ \\
\hline
\end{tabular}

weight of the coelomic cells was $5.6 \mathrm{mg}$, or less than $0.2 \%$ of the gross weight of the worm. While the quantity of coelomic cells is much less than in Amphitrite, the concentration of fat is not so much less (Table 7). Arenicola starves better in the laboratory than most worms, and in November-December worms were kept for 6 weeks at room temperature without food. Those that survived had lost considerable weight, though much of this reduction was due to loss of coelomic fluid. Determinations were made on the fats of normal and starved worms, and it was found that in starved worms there was a greatly increased fat-concentration in the gut and body wall, but the coelomic cells did not seem to be affected (Table 7). In a normal non-breeding worm with a gross weight of $8.0 \mathrm{~g}$, a total of $47.5 \mathrm{mg}$ of fat is located in the body wall, I8. I $\mathrm{mg}$ in the gut and less than $0.2 \mathrm{mg}$ in the coelomic cells.

\section{Glycogen}

The results of determinations of the quantity of glycogen present in various tissues in six randomly selected worms is shown in Table 8. The values for the coelomic cells were negligible and have not been included. It will be seen that the concentration of glycogen is highest in the body wall, the value being of the same order as that in the trephocytes of Amphitrite. 
TABLE 8. ARENICOLA MARINA, CONCENTRATION OF GLYCOGEN IN VARIOUS TISSUES (MG/G WET WEIGHT), AND PROPORTION OF PARTS (APRIL)

\begin{tabular}{|c|c|c|c|c|c|}
\hline $\begin{array}{l}\text { Gross } \\
\text { weight } \\
\text { (g) }\end{array}$ & $\begin{array}{l}\text { Weight } \\
\text { coelomic } \\
\text { contents } \\
\text { (g) }\end{array}$ & $\begin{array}{l}\text { Weight } \\
\text { body wall } \\
\text { (g) }\end{array}$ & $\begin{array}{l}\text { Concentra- } \\
\text { tion glycogen } \\
\text { in body wall } \\
(\mathrm{mg} / \mathrm{g})\end{array}$ & $\begin{array}{l}\text { Weight } \\
\text { gut } \\
\text { (g) }\end{array}$ & $\begin{array}{l}\text { Concentra- } \\
\text { tion glycogen } \\
\text { in gut } \\
(\mathrm{mg} / \mathrm{g})\end{array}$ \\
\hline $3 \cdot 2$ & $\mathrm{I} \cdot 6$ & I.3 & $25 \cdot I$ & 0.3 & II. 4 \\
\hline $9 \cdot 7$ & 4.0 & $\begin{array}{l}5 \cdot 3 \\
2.6\end{array}$ & $\begin{array}{l}22 \cdot 5 \\
20 \cdot 0\end{array}$ & 0.6 & $\begin{array}{r}10 \cdot 6 \\
6.2\end{array}$ \\
\hline $\begin{array}{r}0.0 \\
\text { II }\end{array}$ & $\begin{array}{l}3 \cdot 1 \\
4 \cdot 7\end{array}$ & 5.3 & $20 \cdot 7$ & I. & $\begin{array}{r}0.3 \\
15.6\end{array}$ \\
\hline $\mathrm{II} \cdot 8$ & $4 \cdot 5$ & $6 \cdot 2$ & $12 \cdot 1$ & $I \cdot I$ & $\begin{array}{l}\text { II } \cdot 7 \\
\text { t }\end{array}$ \\
\hline $5 \cdot 3$ & 2.5 & $2 \cdot 4$ & $39 \cdot 4$ & 0.4 & 13.9 \\
\hline- & - & 3.8 & 23.3 & 0.6 & II 6 \\
\hline
\end{tabular}

\section{Histochemical data}

Sudan black B staining showed that fat granules were present in some of the ceolomic cells, but never in great quantities. The oocytes, too, contain little fat as compared with either Amphitrite or Nereis. Glycogen was not demonstrable by Best's carmine in the coelomic cells. In sections of body wall considerable deposits were found in the peritoneum, while fat occurs mainly in the gut epithelium and the epidermis.

\section{Fats}

\section{Nereis diversicolor}

In a previous paper (Dales \& Kennedy, 1954) the seasonal variation in colour in this species was described and it was suggested that the greener specimens most usually encountered in early spring owed their colour to the withdrawal of carotenoids from the epidermis thereby unmasking the biliverdin to which the green colour is due. Determinations of the fat content of the body wall in different worms have been made before and after spawning in order to test the hypothesis that the carotenoid removal is merely a visible manifestation of the withdrawal of the epidermal fats in connexion with the maturation of the oocytes. The results are not conclusive, but are presented here because of the interest of the values for fat and glycogen in the general economy of the animal.

Completely green males just before spawning have an extremely thin body wall and this has a fat content below that measurable in a single worm by the method used. While fats have been removed along with other substances in the tissues phagocytized, there is no evidence that they are withdrawn specifically for utilization in the maturation of the sperm. In ripe females, which are usually greener soon after the spawning period, the fat content is still high. The values for November, January (pre-spawning), and April (post-spawning) do not differ significantly (Table 9). There may still be a real utilization of epidermal fat in the maturation of the oocytes, but the high proportion of muscle included in the body-wall samples analysed may mask the change, for 
there is no doubt that a green male has negligible amounts of fat in the epidermis while a non-breeding worm with an orange hue has values in the order of $16 \mathrm{mg} / \mathrm{g}$. The amount of fat represented by the sperm in the coelom is roughly equivalent to that represented by the oocytes in a mature female of similar size. In April it was found that the gut contains about $20 \mathrm{mg} / \mathrm{g}$ of fat.

TABLE 9. NEREIS DIVERSICOLOR, CONCENTRATION OF FAT IN THE BODY WALL AT DIFFERENT TIMES (MG/G WET WEIGHT). FEMALES

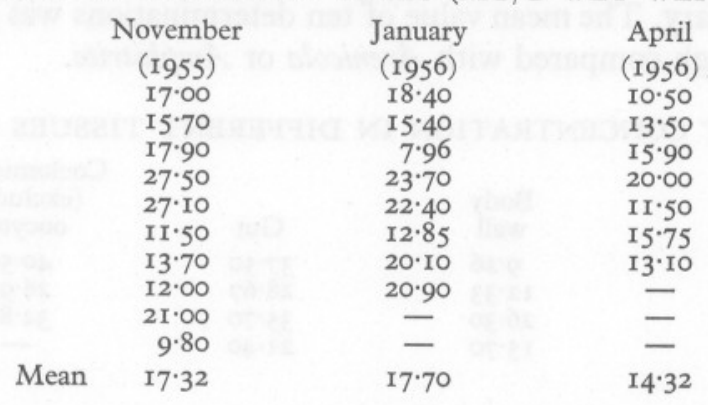

TABLE 10. NEREIS DIVERSICOLOR, ANALYSIS OF OOCYTES

$\begin{array}{lccc} & \begin{array}{c}\text { Fat } \\ \text { concentration } \\ (\mathrm{mg} / \mathrm{g})\end{array} & \begin{array}{c}\text { Glycogen } \\ \text { concentration } \\ (\mathrm{mg} / \mathrm{g})\end{array} & \begin{array}{c}\text { Water } \\ \text { (\% wet weight) }\end{array} \\ \text { I6 Jan. (coelomic) } & 59 \cdot \mathrm{I} & 32 \cdot 9 & 20 \cdot 9 \\ \text { I9 Feb. (released) } & 97 \cdot 0 & 57 \cdot 5 & 57 \cdot 5\end{array}$

TABLE 11. NEREIS DIVERSICOLOR, TOTAL WEIGHT OF OOCYTES IN RIPE FEMALES (g)

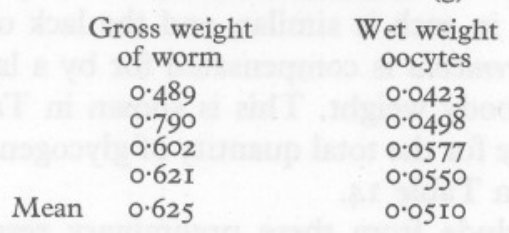

In a ripe female of $625 \mathrm{mg}$ gross weight, the coelomic fluid weighs about $75 \mathrm{mg}$. The tissues have a fat content of about $15.7 \mathrm{mg} / \mathrm{g}$ and the ripe eggs $90 \mathrm{mg} / \mathrm{g}$ (Table 9). A worm of this size has about $50 \mathrm{mg}$ of eggs, or a total of $4.5 \mathrm{mg}$ of fat in the eggs - about half the quantity in the body wall (Table 9). If all the fat required for the maturation of the oocytes were withdrawn from the body wall alone, a much greater variation in the body wall values would be expected. The fat and glycogen content of the oocytes are shown in Table ro. Clearly, either only some of the fat is withdrawn from the body wall or there is a continual replacement of fat, implying a resorption of tissue from other sites or continued feeding by the animal prior to spawning. It has been remarked already (Dales \& Kennedy, 1954) that females remain much more healthy prior to spawning than the males, in which much more phagocytosis occurs 
and which may well be incapable of feeding just before the spawning period. As far as the males are concerned all the fat required for the maturation and nourishment of the sperm could easily be provided by the amount in the body wall alone.

\section{Glycogen}

Some determinations of the concentration of glycogen in the body wall were made in January. The mean value of ten determinations was $34.3 \mathrm{mg} / \mathrm{g}$, a value which is high compared with Arenicola or Amphitrite.

TABLE 12. FAT CONCENTRATION IN DIFFERENT $\begin{gathered}\text { TISSUES }(\mathrm{MG} / \mathrm{G}) \\ \text { Coelomic cells } \\ \text { (excluding } \\ \text { oocytes) }\end{gathered}$
$\begin{array}{cccc}\text { Body } & \text { Gall } & 40 \cdot 50 \\ \text { Amphitrite } & 9 \cdot 26 & 37 \cdot 50 & 26 \cdot 93 \\ \text { Arenicola } & 12 \cdot 33 & 28 \cdot 67 & 32 \cdot 80 \\ \text { Terebella } & 26 \cdot 30 & 35 \cdot 70 & - \\ \text { Nereis } & \mathrm{I} 5 \cdot 70 & 2 \mathrm{I} \cdot 40 & \end{array}$

\section{DISCUSSION}

In Table 12 are summarized all the mean values of fat concentration in the four species studied. It will be noticed that there is a rough correspondence in each species between the values for gut and coelomic cells. While Arenicola and Amphitrite are similar in this respect, the proportion which each part represents in the total body weight is different. If the total quantities of fat are calculated for each species in worms of similar size (say Io g) it appears that the total quantity of fat in each is similar, and the lack of a well-developed trephocyte system in Arenicola is compensated for by a larger proportion of body wall in the total body weight. This is shown in Table I3. The same comparison may be made for the total quantity of glycogen present, and these calculations are shown in Table I4.

It is difficult to conclude from these preliminary results how far these variations reflect different food depots, but the increase in fat concentration in all tissues in late summer in Amphitrite and a corresponding decrease in winter suggests that the fats are both deposited and withdrawn from the gut, the body wall, and the trephocytes during the maturation of the gametes. The high fat values for the gut and the histochemical evidence of its distribution in the epithelial cells suggests that the physiological difficulty of transporting fats in the blood is partly overcome by storing them primarily in the epithelial cells of the gut itself, though perhaps later the fat may be transferred by the blood stream to the epidermis, by the peritoneum to the coelomic fluid, or may be removed by amoebocytes. Except in the event of direct removal by amoebocytes, the fat must first enter the blood stream, since the epithelial cells are separated from the muscular and peritoneal layers by the gut sinus. This 
interpretation would concur with the views of Romieu (1923) and Kollman (1908) that the trephocytes are amoebocytes which have taken up fat granules.

The similar appearance of the epidermis and coelomic cells that has been noted in Nereis (Dales \& Kennedy, I954), Owenia (Dales 1957) and in the dark and light forms of Amphitrite (Kennedy \& Dales, unpublished), suggests a close interrelationship between them. Fretter (1953) found that the amoebocytes in Platynereis dumerilii took up radioactive strontium and yttrium from the sea water, both through the gut and the epidermis, and that amoebocytes containing these isotopes were most frequent in the epidermis. Fretter, following Liebman (1946), distinguishes these amoebocytes from trephocytes which did not, apparently take up the isotopes. In Amphitrite trephocytes in the coelom certainly show no amoebic powers, though they may be kept healthy

TABLE 13. TOTAL QUANTITY OF FAT IN $10 \mathrm{G}$ WORMS (MG) (NOVEMBER-FEBRUARY)

$\begin{array}{lcccc} & \begin{array}{c}\text { Body } \\ \text { wall }\end{array} & \text { Gut } & \begin{array}{c}\text { Coelomic } \\ \text { cells }\end{array} & \text { Total } \\ \text { Arenicola } & 55 \cdot 3 & 20 \cdot 0 & 0 \cdot 135 & 75 \cdot 4 \\ \text { Amphitrite } & 27 \cdot 8 & 25 \cdot 1 & 17 \cdot 400 & 70 \cdot 3\end{array}$

TABLE 14. TOTAL QUANTITY OF GLYCOGEN

IN $10 \mathrm{G}$ WORMS (MG) (APRIL)

$\begin{array}{lcccc} & \begin{array}{c}\text { Body } \\ \text { wall }\end{array} & \text { Gut } & \begin{array}{c}\text { Coelomic } \\ \text { cells }\end{array} & \text { Total } \\ \text { Arenicola } & 88.5 & 7.0 & - & 95.5 \\ \text { Amphitrite } & 37.0 & 1.9 & 36.6 & 74.5\end{array}$

in a hanging drop in a sealed slide for many days. Fauré-Fremiet's observations (I929) confirm this. The amount of fat increases with increasing size of the trephocyte, but the largest contain few granules. This suggests that the fat is either synthesized by the cell or taken up directly from the coelomic fluid, and eventually discharged for the benefit of younger cells or growing gametes. It is just possible that there is some correspondence between the glucose in the body fluid, and the glycogen and fat in the trephocyte, and it is planned to investigate this further. Seton \& Wilbur (1949) have made some determinations of the glucose in the coelomic fluid, which was found to increase with rising temperature. In some preliminary determinations in Amphitrite in the present work, the glucose content was found to increase under various adverse conditions at different temperatures, but insufficient observations have been made as yet to make any conclusions about these experiments.

The trephocytes in Amphitrite undoubtedly contain substances other than glycogen and fat, but these have not yet been determined and are beyond the scope of this paper. Both Fauré-Fremiet (I929) and Romieu (I923) state that albuminoids are present, and Romieu (1923) also identifies various excretory 
substances. Von Brand (I927), Fauré-Fremiet (I929) and Wilbur \& Bayors (1947) are the only previous workers who have published determinations of fat content in polychaete tissues. Fauré-Fremiet (1929) found a total fat content in the trephocytes of Amphitrite of I.23\% (wet weight), and Wilbur \& Bayors (1947) found a total lipid content in Amphitrite ornata of $3.15 \%$, Arenicola marina $\mathrm{I} \cdot 22 \%$ and Nereis pelagica of $2 \cdot 17 \%$ of the total wet weight. Von Brand (1927) found that fat accounted for $3.8 \mathrm{I} \%$ in $N$. pelagica, 0.54 in $A$. marina (wet weight). These values are not dissimilar to those obtained in the present work, but they have little relevance to the present problem since they are overall values, and no information is given about the state of the worms. Alscher (1949) has also made observations on the trephocytes in Arenicola marina and Amphitrite ornata and has made counts of the number of fat granules in different types and size of coelomic cell. The counts show that the amount of fat present within each size-group of cell is very variable, but in both species the smaller cells have fewer granules, and the largest cells have the widest spread in number with a possible inference of loss of granules in the larger and older cells.

While the experiments on the effect of starvation are not conclusive, the rise of fat concentration after starving in Arenicola is very reminiscent of the 'fatty liver' condition in vertebrates, but it may be due directly to substances other than fats being withdrawn at times of inanition. On the other hand, in the male Nereis diversicolor the gut and the body wall are eroded almost completely immediately before the spawning period, and the total fat content is considerably less than its normal value. It is proposed to examine the effects of starvation more closely, especially in relation to glycogen which has not yet been measured in starving worms.

The increase in the number of trephocytes during the maturation of the gametes in Nereis (Dales, I950) suggests that these cells are primarily, if not solely, concerned with this function. The terebellids, on the other hand, maintain a large number of trephocytes which does not vary appreciably during the year, though there is a considerable loss when spawning occurs. While Liebman (1946) may be correct in assuming a dual origin for the amoebocytes and trephocytes in earthworms, there is no evidence for this in Amphitrite. The assumption that the trephocytes in earthworms are chloragocytes which have become free may be correct, but these trephocytes may not be comparable with the trephocytes in Amphitrite. Terebellids do not appear to have any cells on the outside of the gut or on the dorsal vessel which could be described as chloragocytes, and green or yellow granules are found only in the heart body (Kennedy \& Dales, unpublished). There is no evidence that the trephocytes in Amphitrite are derived from the heart body, or that this organ ever liberates cells into the blood stream in which they are virtually absent. Ashworth (I904) describes intravasal tissue in the heart of Arenicola, but this is very small compared with that in Amphitrite. Kermack (1955) has given some account of 
the activity of amoebocytes after injection of ink particles into the gut of Arenicola, amoebocytes laden with ink particles collecting in the intravasal tissue and in the coelom. This is interesting in demonstrating one way in which substances may be removed directly from the gut. The intravasal tissue contains chloragosomes, but chloragocytes are found also in the coelomic epithelium (Schneider, I899). The relationships of the chloragocytes and the amoebocytes and trephocytes are not known. Some of these problems are now being investigated.

\section{SUMMARY}

Determinations of the concentration of fat and glycogen in the body wall, in different parts of the gut and in the coelomic cells are described in Amphitrite and Arenicola. It is suggested that the trephocyte system constitutes a store of fat and glycogen derived from a primary store in the absorptive parts of the gut itself. In Arenicola and Nereis surplus fat is removed from the gut itself through the blood or directly by amoebocytes; the fat deposited in the epidermis and the glycogen in the peritoneum. In these worms the coelomic trephocytes are solely concerned with the maturation of the gametes. No relationship can be established between these cells and the chloragocytes. In Amphitrite and Terebella fat is stored also in the coelomic trephocytes which may derive their contents directly from the gut or from the body wall. Glycogen is stored in the trephocytes in Amphitrite, and in Arenicola in the peritoneum. Thus while large amounts of fat and glycogen are found in the trephocytes in Amphitrite, the total amount present in the body is no more than in Arenicola which lacks a well-developed trephocyte system, and in this species a larger proportion of fat and glycogen is found in the body wall.

\section{REFERENCES}

ABDEL-Fattah, R. F., 1955. The chloragogen tissue of earthworms and its relation to urea metabolism. Proc. Egypt. Acad. Sci., Vol. 10, pp. 36-50.

ALSCHER, R. P., I949. Description of, and localization in, cells of body cavity fluid of Arenicola marina (Lamarck) and Amphitrite ornata (Leidy). Biol. Bull., Woods Hole, Vol. 97, pp. 253-4.

AshworTH, J. H., I904. Arenicola. L.M.B.C. Memoirs, Vol. II, II8 pp. London: Williams and Norgate.

BAKER, J. R., 1946. The histochemical recognition of lipine. Quart. F. micr. Sci., Vol. 87, pp. 44I-70.

BLOOR, W. R., I928. The determination of small amounts of lipid in blood plasma. f. biol. Chem., Vol. 77, pp. 53-73.

- I 1929 . The oxidative determination of phospholipid (lecithin and cephalin) in blood and tissues. F. biol. Chem. Vol. 82, pp. 273-86.

BRAND, T.F.voN, 1927. Stoffbestand und Ernährung einiger Polychaëten und anderer mariner Würmer. Z. vergl. Physiol., Bd. 5, pp 643-98.

Carn, A. J., 1947. The use of nile blue in the examination of lipoids. Quart. F. micr. Sci., Vol. 88, pp. 383-92. 
CASSElman, W. G. B., I954. Acetylated sudan black B as a more specific histochemical reagent for lipides. Quart. F. micr. Sci., Vol. 95, pp. 32I-2.

Chiffelle, T. L. \& Putt, F. A., I95I. Propylene and ethylene glycol as solvents for sudan IV and sudan black B. Stain Tech., Vol. 26, pp. 5I-6.

Clapark̀de, E., I868. Les annélides chétopodes du Golfe de Naples. 500 pp. Geneva: Georg.

— 1873. Recherches sur la structure des Annélides Sédentaires. 200 pp. Geneva: Georg.

Cú́NOT, L., I891. Études sur le sang et le glandes lymphatiques dans la série animale. Arch. Zool. exp. gén., Sér. 9, T. 2, pp. 365-475.

- - 1898. Études physiologiques sur les Oligochètes. Arch. biol., T. I5, pp. 79-124.

DALES, R. P., I950. The reproduction and larval development of Nereis diversicolor O. F. Müller. F. mar biol. Ass. U.K., Vol. 29, pp. 321-60.

— 1955. Feeding and digestion in terebellid polychaetes. F. mar. biol. Ass. U.K., Vol. 34 , pp. 55-79.

- 1957. The feeding mechanism and morphology of the gut of Owenia fusiformis delle Chiaje. 7. mar. biol. Ass. U.K., Vol. 36, pp. 8I-9.

DAles, R. P. \& KenNEDY, G. Y., I954. On the diverse colours of Nereis diversicolor. F. mar. biol. Ass. U.K., Vol. 33. pp. 699-708.

FAURÉ-FrEMIET, E., I929. Constitution et proprietes physico-chimiques des éléocytes d'Amphitrite johnstoni (Malmgren). Protoplasma, Vol. 5, pp. 32 I-37.

FRETTER, V., I953. Experiments with radioactive strontium $\left({ }^{90} \mathrm{Sr}\right)$ on certain molluscs and polychaetes. F. mar. biol. Ass. U.K., Vol. 32, pp. 367-84.

FreUdWEILER, H., I905. Studien über das Gefäßsystem niederer Oligochäten. Fena. Z. Naturw., Bd. 40, pp. 383-422.

HAGEDORN, H. C. \& JENSEN, N., 1923. Zur Mikrobestimmung des Blutzuckers mittels Ferricyanid. Biochem. Z., Bd. I35, pp. 46-58.

HeRPIN, R., I92I. Sur l'origine et le rôle des cellules à résèrves de la cavité générale chez Perinereis cultrifera (Gr.) et Perinereis Marioni (Aud. et Edw.) et la différenciation précoce de leurs œufs. C.R. Acad. Sci., Paris., T. 173, pp. 249-52.

Issel, R., I905. Intorno agli escreti dei linfociti. Arch. Zool. (ital.), Napoli, Vol. 2, pp. $125-35$.

KenNedy, G. Y., 1953. Partition paper chromatography of the porphyrins. Scand. F. clin. Lab. Invest., Vol. 5, pp. $28 \mathrm{I}-4$.

KERMACK, D. M., I955. The anatomy and physiology of the gut of the polychaete Arenicola marina (L.). Proc. zool. Soc. Lond., Vol. 125, pp. 347-8I.

Kollman, M., 1908. Notes sur les réserves albuminoides des Insectes et des Annélides. Bull Soc. zool. Fr., T. 34, pp. 149-55.

LIEBMAN, E., I946. On trephocytes and trephocytosis; a study on the role of leucocytes in nutrition and growth. Growth, Vol. I0, pp. 291-330.

Pearse, A. G. E., 1953. Histochemistry, Theoretical and Applied, 530 pp. London: Churchill.

PICTON, L. J., I898. On the heart body and coelomic fluid of certain polychaetes. Quart. F. micr. Sci., Vol. 4I, pp. 263-302.

RICE, W. J., I902. Studies in earthworm chloragogue. Biol. Bull., Woods Hole, Vol. 3, pp. 88-94.

Romieu, M., I921. Les inclusions cristallines des éléocytes de Nereis et leurs relations avec la granulation éosinophile. C.R. Acad. Sci., Paris, T. 168, pp. 367-9.

— I923. Recherches histophysiologiques sur le sang et sur le corps cardiaque des Annélides polychètes. Thès. Fac. Sci. Univ. Paris, 336 pp., Paris: Doin.

RosA, D., I896. I linfociti degli Oligocheti. Ricerche istologiche. Mem. R. Accad. Torino, Vol. 46, pp. 149-78. 
RosA, D., 1898. I pretesi rapporti genetici tra i linfociti ed il chloragogeno. Atti Accad., Torino, Vol. 33, pp. 6I2-37.

SchaeppI, T., I894. Das Chloragogen von Ophelia radiata. Fena Z. Naturw., Bd. 28, pp. 249-93.

SCHNEIDER, G., I896. Über phagocytäre Organe und Chloragogenzellen der Oligochäten. Z. wiss. Zool., Bd. 61, pp. 363-92.

1897. UUber die Segmentalorgane und den Herzkörper einiger Polychäten. Arb. d. Kaiserl. Naturf. Ges. St. Petersburg, Vol. 27, pp. 135-7.

1899. Über Phagocytose und Excretion bei den Anneliden. Z. wiss. Zool., Bd. 66, pp. 497-520.

Seton, E. \& Wilbur, G. G., I949. Glucose metabolism in marine annelids. Biol. Bull., Woods Hole, Vol. 97, p. 246.

SMYTH, J. D. \& Hopkins, C. A., I948. Ester wax as a medium for embedding tissue for the histological demonstration of glycogen. Quart. F. micr. Sci., Vol. 89, pp. $43 \mathrm{I}-5$.

SPERRY, W. M., 1938. A micromethod for the determination of the total and free cholesterol. Amer. F. clin. Path., Tech. Suppl., Vol. 2, pp. 9I-9.

Sterling, S., 1908. Das Blutgefäßsystem der Oligochäten. Fena Z. Naturw., Bd. 44, pp. 253-352.

WILBUR, C. G. \& BAyors, W. M., 1947. A comparative study of the lipids in some marine annelids. Biol. Bull., Woods Hole, Vol. 93, pp. 99-Ior.

WIILEM, V. \& MinNe, A., I900. Recherches sur l'excrétion chez quelques Annélides. Mém. Acad. R. Belg. Cl. Sci., T. 58, pp. I-73.

\section{APPENDIX \\ ANALYSIS OF FATS \\ Extraction}

Tissues were dried on filter-paper and the quantity extracted weighed by difference before being macerated in a Griffith pattern tissue grinder. Extraction was effected by refluxing with fifty times the weight of the tissue with $95 \%$ ethanol:peroxide-free ether 3:I mixture overnight. Larger quantities of tissue were extracted in a Soxhlet apparatus. The extract was filtered through fat-free paper and made up to $50 \mathrm{ml}$. The efficiency of extraction was tested with known quantities (50-100 mg) of pure oleic acid absorbed on filter paper.

\section{Estimation of total fatty acids plus sterols}

A $20 \mathrm{ml}$. portion of the extract was measured accurately into a wide-necked Ehrlenmeyer flask, and $2 \mathrm{ml}$. of sodium ethoxide added. This was then placed in a ventilated electric oven at $90^{\circ} \mathrm{C}$ and allowed to evaporate to about $2 \mathrm{ml}$. This was found more satisfactory than evaporating on a water-bath owing to loss by spitting. The pasty residue was dried in a current of air, and the fatty acids liberated by the addition of $\mathrm{I} \mathrm{ml}$. of dil. $\mathrm{H}_{2} \mathrm{SO}_{4}$ and heating on a boiling water-bath for $\mathrm{I} \mathrm{min}$. The fatty acids were then dissolved in successive $3 \mathrm{ml}$. portions of boiling $40-60$ light petroleum by rotating over the water-bath for $3 \mathrm{~min}$, the combined extracts being made up to $25 \mathrm{ml}$. A $10 \mathrm{ml}$. portion of this was carefully measured into a $150 \mathrm{ml}$. conical ground glass-stoppered flask and evaporated to dryness, the last traces being blown off in a current of air. A control flask was started at this stage. $5 \mathrm{ml}$. of the silver chromate: $\mathrm{H}_{2} \mathrm{SO}_{4}$ reagent and exactly $3 \mathrm{ml}$. of $\mathrm{I} \cdot \mathrm{O} \mathrm{N}$ potassium dichromate were then added, the contents mixed, the flask stoppered and placed in the oven at $90^{\circ} \mathrm{C}$ for $90 \mathrm{~min}$. In the event of all the oxidant becoming used up after $5 \mathrm{~min}$, the light 
petroleum extract was diluted, and the process repeated. The flasks were placed on a bed of sand in the oven to maintain a more even temperature. After $90 \mathrm{~min}$ the contents were diluted to about $100 \mathrm{ml}$. with cold distilled water and carefully washed out into a $250 \mathrm{ml}$. conical flask; $10 \mathrm{ml}$. of $10 \%$ potassium iodide added and the mixture immediately titrated against $\mathrm{O} \cdot \mathrm{I} \mathrm{N}$ sodium thiosulphate, using starch indicator. The difference in the titration values between the samples and the control is a measure of the amount of oxidant reduced by the fatty acids. Usually four flasks were run at once. Values within $\pm 2 \%$ were obtained with pure oleic acid. All steps in the procedure were tested, and most loss occurs in the oxidation.

\section{Estimation of phospholipids}

A $20 \mathrm{ml}$. portion of the ethanol: ether extract was evaporated to dryness in a $50 \mathrm{ml}$. beaker. The residue was then extracted with $3 \mathrm{ml}$. portions of boiling 40:60 light petroleum and the extracts combined in a $15 \mathrm{ml}$. centrifuge tube. Any sediment was centrifuged out and the clear liquid decanted into another tube if necessary and allowed to evaporate to $2 \mathrm{ml}$. To the solution was then added $7 \mathrm{ml}$. of acetone and $0.1 \mathrm{ml}$. of magnesium chloride in ethanol (saturated solution), the solutions mixed and the phospholipid precipitate centrifuged down. The supernatant liquid was then carefully drawn off, the gummy precipitate kneaded with successive portions of acetone, and finally allowed to dry by inverting the tube on filter-paper. The precipitate was then dissolved in moist ether, with warming, and the solution transformed to the $150 \mathrm{ml}$. oxidation flask, the ether evaporated in a current of air and the phospholipid estimated by the chromic acid oxidation mixture as before. Bloor's correction factor was applied in the calculations.

\section{Estimation of total sterols (free and combined)}

Exactly I ml. of the ethanol:ether extract was transferred to a $15 \mathrm{ml}$. centrifuge tube, $0.05 \mathrm{ml}$. of $50 \% \mathrm{KOH}$ added and the mixture warmed to $40^{\circ} \mathrm{C}$ for $30 \mathrm{~min}$. After cooling the mixture was neutralized with $5 \% \mathrm{HCl}$ using phenolphthalein as indicator. I ml. of I \% digitonin in $50 \%$ ethanol was added, stirred with a glass rod and allowed to stand $24 \mathrm{~h}$. The precipitate was centrifuged down at 2500 r.p.m. for I5 $\mathrm{min}$, the supernatant carefully removed, the rod replaced and the tube vigorously washed down with $2 \mathrm{ml}$. acetone: ether $\mathrm{I}: 2$ mixture from a syringe; after further centrifugation, the precipitate was washed and centrifuged twice with pure ether, the precipitate being then dried at $40^{\circ} \mathrm{C}$ in a current of air. The tube was kept in a desiccator until ready to develop the colour reaction.

The precipitate was then dissolved in $\mathrm{I} \mathrm{ml}$. glacial acetic acid; warming to $40^{\circ} \mathrm{C}$ and stirring with original glass rod was usually necessary. Exactly $2 \cdot \mathrm{I} \mathrm{ml}$. of acetic anhydride: $\mathrm{H}_{2} \mathrm{SO}_{4}$ mixture was added and the tube with controls stirred well and placed in an incubator at $25^{\circ} \mathrm{C}$ for exactly $30 \mathrm{~min}$. The density of the colour was measured at $670 \mathrm{~m} \mu$ using a 'Unicam' S.P. 600 Quartz spectrophotometer, and the amount of sterol present calculated from a standardization curve obtained by successive dilution of a known solution of pure cholesterol.

The above description includes all the data on the variations in the general methods of Bloor (1928, I929) and Sperry (1938). Reference should be made to the original papers for details of making and purity of the reagents required. 